Vitamins in Theory and Practice

By Dr. Leslie H. Harris. Pp. xix +242 . (Cambridge : At the University Press, 1937.) 8s. 6d. net.

Tre first edition of Dr. Harris's book was published at the end of 1935 and reviewed in Nature in the spring of 1936 (137, 868). Its deserved success is doubtless one reason why a new edition has been needed so soon; another is the speed with which advances in vitamin chemistry have been made during the last eighteen months, a speed unusual even in this exceptionally fast-moving branch of biochemistry.

During that period the exact structures of aneurin chloride (vitamin $B_{1}$ ) and of lactoflavin (part of the 'vitamin $B_{2}$ complex') have been made known, and both have been completely synthesized. The detailed structures of two antirachitic vitamins, calciferol (vitamin $\mathrm{D}_{2}$ ) and the 'natural' vitamin of halibut and tunny liver oils (vitamin $\mathrm{D}_{3}$ ) have been worked out and a generally accepted formula has been proposed for each; the latter has been prepared from inactive substances, both 'natural' and of laboratory origin, and it has also been obtained crystalline, though too recently for the fact to be recorded by Dr. Harris. The claim by Evans to have isolated vitamin $\mathrm{E}$, which he calls "tocopherol", is accepted by Dr. Harris, but he would not find that all workers in this field agree with him on the matter.

Apart from expanding his book to include these items of new discovery, the author has made few additions. He might, perhaps, with advantage have included reference to the more recent work on the treatment of habitual abortion with wheat-germ oil or extracts made from it (Shute, Watson, Currie), especially as this work confirms the original observations of Vogt-Möller, recorded in this edition in words identical with those used in the first. But Dr. Harris is perhaps wise in a book of this nature, intended for lay consumption, to err on the side of caution.

A. L. Bacharach.

Thirty Years of Nature Photography:

a Personal Record of Two Observers. By Seton Gordon. Pp. $x i+100+108$. (London, New York, Toronto and Melbourne: Cassell and Co., Ltd., 1936.) 21s. net.

THE author has been photographing birds and their nests since 1903, inspired originally by the books of Richard Kearton. His wife had also observed and photographed sea and moorland birds, and after marriage the two enthusiasts helped each other in this fascinating pursuit. The beautiful plates of this book are the result of their collaboration, the letterpress explaining the methods used, with particular emphasis on the necessity for a 'hide', and for two observers to use it.

There are photographs of sea birds, moorland birds, a few of seal and deer, and two remarkable pictures of crested tits. The account of the taking of these photographs shows that considerable physical fortitude, besides infinite skill and patience, went to the making of a book which admits the reader to the intimate family life of these untamed creatures.
Most of the photography was done with a large camera from a hide, a hand camera being used for sea birds only. The photography of the latter is comparatively simple as they are not very shy, the main difficulty being the inaccessibility of their haunts. But photographs such as those of the golden eagles caressing each other above their eaglet, feeding and sheltering the eaglet, and of the hooded crow with her nestling are wonderful achievements, elike in photographic skill and bird study. Regarded pictorially, the 'close-ups' are better than such pictures as "Stags Crossing a River", where the lens is too good for the picture, the deep focus giving no sense of recession.

The author comments on the difficulties found in enforcing the Wild Birds Protection Act. Books such as this must, we hope, turn a reader's thoughts to study of a bird as a lovely sentient being, rather than as a stuffed corpse or a blown egg.

\section{Flora of Jamaica :}

containing Descriptions of the Flowering Plants known from the Island. By William Fawcett and Dr. Alfred Barton Rendle. Vol. 7 : DicotyledonsFamilies Rubiaceæ to Compositæ. By the late Spencer Le Marchant Moore and A. B. Rendle. Pp. ix +303 . (London: British Museum (Natural History), 1936.) $15 s$.

THE continuation of this valuable work is very welcome, and we note with pleasure that there is every hope of its speedy completion. The present volume is filled almost entirely by the accounts of the Rubiaceæ and Compositæ, which were prepared by the late Mr. Spencer Moore and have been completed by Dr A. B. Rendle. The latter author has also worked out the Campanulaceæ, and has success. fully unravelled the difficulties which obscured the identity of some of the ten species of Lobelia occurring in Jamaica. All students of tropical American plants will be grateful for the attention to nomenclature and synonymy, the care in examining historic types, and the general finish which have from the first been marks of this distinguished production.

Einführung in die Vektor- und Tensor-rechnung: unter besonderer Berücksichtigung ihrer physikalischen Bedeutung. Von Prof. Dr. Harry Schmidt. Pp. vi+125. (Leipzig: Max Jänecke, 1935.) 5.80 gold marks.

THIs is an excellent account of vector analysis, starting at the beginning, based on sound mathematical principles, and clearly explained. The vector theorems are well illustrated by hydrodynamical applications; the tensor of the second order (the work is carried no further) is exemplified by the theory of elasticity. The author believes that an exact treatment need not be more difficult, and is certainly easier to understand, than a popular exposition lacking in rigour and based on intuition. With this we entirely agree, and can recommend this book to all who wish to learn vector methods and their application. 